\title{
Human CHD and Pig Cardiac Mortality in Finland during 1954-86
}

\author{
Töysä $T^{1}$, Hanninen $\mathbf{0}^{2}$, Haaranen $\mathrm{S}^{3}$ \\ ${ }^{1}$ Licentiate of Medicine, Specialty General Practice, Rehabilitation Hospital Vetrea Terveys Oy \\ ${ }^{2}$ Prof. em. Physiol, Dr. Med. Sci, Ph.D, Department of Physiology, University of Eastern Finland \\ ${ }^{3}$ Researcher, Veterinary Surgeon Siilinjärvi, Finland. (1928-2014)
}

Received: February 09, 2018; Published: February 20, 2018

*Corresponding author: Töysa T, Licentiate of Medicine, Specialty General Practice, Rehabilitation Hospital Vetrea Terveys Oy, Pohjolankatu 15, FI-74100 Iisalmi, Finland. Email: timo.toysa@fimnet.fi

\begin{abstract}
Introduction: Environmental factors affect on foodstuff quality. Because pigs and humans eat same foodstuffs (cereals, potatoes and dairy products) we could expect that time-related changes in them could show simultaneous health changes in both of them. In this study are assayed female (F) and male (M) mortality changes in coronary heart disease (CHD) and their associations with pig autopsy parameters. Data are presented from period 1951-2000, statistically analyzed from period 1954-86 including autopsy density per 100,000 pigs [A.1/100,000], autopsy percents of microangiopathy [MAP.a-\%] and cardiovascular diagnoses total [CVD.tot.a-\%], additionally visually analyzed myocardial degeneration, Hepatosis diaetetica [HeD.a-\%] and skeletal muscle degeneration [SMuD.a-\%].
\end{abstract}

Results: During 1954-86 [A.1/100,000], [MAP.a-\%], [CVD.tot.a-\%] and combined regressions with [MAP.a-\%;A.1/100,000] and [CVD.a$\% ; A .1 / 100,000]$ explained stronger F.CHD than M.CHD. All the female associations were significant (weakest by MAP.a-\%: $\mathrm{p}=0.001$, not below 0.001). Autopsy density associated stronger than the other given single parameters with F.CHD and M.CHD. [MyCD.a-\%] was associated with changes in Hepatopathia diaetetica [HeD.a-\%]. It decreased deeply in 1963 and discontinued since 1970.

Discussion: Similar variation in F.CHD and pig cardiac mortality is suggestive on common, obviously dietary factors. In this article is discussed on exogenous grain fat peroxides, which are known in the etiology of livestock diseases, their associations with climatic factors, farming procedures and food processing. These changes have been counteracted by changes in feed supplementation, fertilization, agricultural procedures and grain farming shift southwestwards. F.CHD and Pig MAP decline below their 1957 levels until 1972, before respective male CHD decline, can be explained by lesser tobacco consumption.

Conclusions: Pig cardiac mortality associated significantly with female CHD, less significantly with male CHD. These associations seem possible to be explained by variation inside the foodstuffs and different smoking habits. Food peroxides are discussed. Different opinions and the great database of veterinary surgeons suggest that co-operation by faculties of human and veterinary medicine is desirable.

Keywords: Human; Pig; Myocardial; Epidemics; Grain Fats; Peroxides; Silicon; Magnesium; Selenium

\section{Introduction}

In epidemiological studies foodstuff composition tables can be misleading [1]. Pigs eat the same food as humans (cereals, potatoes and milk products) and are free from the diversity in socio-economic status, tobacco and alcohol consumption. Their life span is ca six months. That's why it was supposed that their health changes could nearly immediately indicate changes in the basic foodstuffs and the role of dietary factors in the human health. In this study are benefited pig cardiac mortality data and assessed it with female and male CHD. Additionally to the general etiological factors are introduced exogenous peroxides [2].

According to Grant (1961) [3] MAP (dietetic microangiopathy in pigs, Mulberry heart disease).Means “... vascular lesions in the capillaries and small muscular vessels of the myocardium (cardiac MAP) and sometimes in other tissues (extracardiac MAP). MAP may follow an episodic pattern; if a pig survives an episode the lesions recognized as initial-phase MAP can then give a way to changes aiming at restoration of vascular structure, restitutionphase MAP." Initial-phase MAP can include "vascular engorgement, haemorrhage, (and secondary) degeneration of myocardial fibers, sometimes exudative inflammatory reaction" and restitution-phase MAP can be associated with myocardial scarring. In histological examination is seen partial or total occlusion of capillaries and arterioles caused by PAS-positive material inside capillaries and subendothelially to arterioles and capillaries, too. It can be 
associated with hemolysis and thrombopenia, so resembling human "Thrombotic thrombocytopenic purpura" [3]. The affected pigs were in good nutritional state, weighting 20 to $35 \mathrm{~kg}$ [3]. In autopsy are seen typically vivid wine-red mottling, transudations and signs of acute circulatory failure [3].

Thafvelin [2] and Grant [3] could produce MAP with experimental diet containing peroxides and could relieve it with selenium (Se) and vitamin E [3], but believed that MAP does not belong to typical antioxidant deficiency syndrome family [3]. The role of magnesium in MAP has been supported by observations: $\mathrm{Mg}$ supplementation has relieved dramatically MAP pigs resistant to Se-vit-E treatments [4] and MAP pigs have had elevated Ca/Mg ratio in cardiac and hepatic tissues [5]. Role of $\mathrm{Mg}$ in human diseases is supported by the Mg reference values of plasma: for humans (0.71$0.94 \mathrm{mmol} / \mathrm{L}$ ) [6] and for pigs (0.97-1.45 mmol) [7]. Mg has been associated with platelet dependent thrombosis, too [8].

Hepatosis diaetetica (HeD), Myocardial and Skeletal muscle degeneration (MyCD and SMuD, respectively) are known to be associated with excess of (rancid) polyunsaturated fats (PUFA), deficiency of selenium (Se) and vitamin E [9]. HeD has been labeled as "toxic liver dystrophy", which resembles yellow atrophy of men [10]. Old textbooks wrote that human CHD mortality is not always associated with coronary occlusion, includes infarcts of different ages and seem to be associated with changes in coagulation. When additionally pig cardiac diseases are associated with peroxides [11] and Mg [12], pig and human cardiac diseases have much in common. The primary aim of this study is to assess the compliance between human and pig cardiac mortality, not to find its complete explanation.

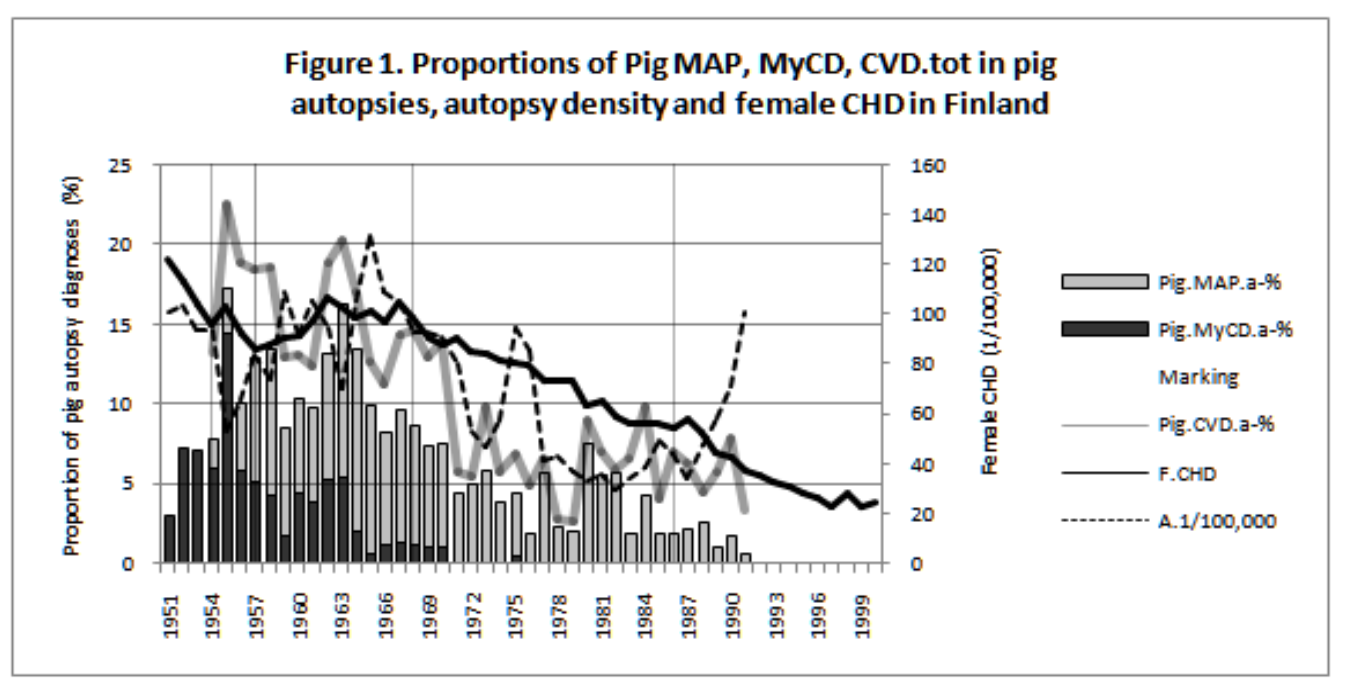

Figure 1: Shows development in female CHD and available data concerning autopsy proportions of pig CVD.tot, MAP and MyCD, as well as autopsy density. The first MAP-diagnoses ("enzootischer Herztod") are from 1954.

\section{Materials and Methods}

CHD data for period 1951-68 are from Valkonen and Martikainen (1990) [13] and for period 1969-2000 from Statistics Finland [14]. F.CHD for 1951-68 has been measured as mm from Figure 1 [13] (magnified so that distance between 50 and 150 on logarithmic Y-axis was $103.5 \mathrm{~mm}$ ) and calculated by equation:

POTENCE $(10 ; \operatorname{LOG10}(50)+Y / Y . \max (\mathrm{mm}) *(\operatorname{LOG10}(150)-\operatorname{LOG10}(50)))$

and then subtracted by mean deviation from values of Statistics Finland in 1969-75 (1.5). Respectively from the same figure has been estimated M.CHD for period 1951-68 Annual number of pigs are from Statistics Finland $[15,16,17,18]$. Data including pig autopsies, annual number of MAP, MyCD, SMuD, HeD and annual summary of all cardio-vascular cases including MAP and MyCD (CVD.tot) are from National Veterinary Institute (Helsinki) from 1951-91, Regional Veterinary Laboratory of Kuopio (since 1982) and Seinäjoki (since 1984) [19] (Table 1). First cases of Pig MyCD are from 1951, HeD from 1953, MAP and SMuD from 1954. The diagnose-label of MAP was "enzootischer Herztod" in 1954-63 as by Haaranen (1957) [20].

Table 1: F.CHD with calculations, M.CHD, number of pigs, pig autopsies (N), Pig autopsy density, Autopsy proportions (a-\%) of Pig MAP, Myocardial degeneration (MyCD), CVD total (CVD.tot), Hepatopathia diaetetica (HeD) and Skeletal Muscle degeneration (SMuD).

\begin{tabular}{|c|c|c|c|c|c|c|c|c|c|c|c|c|}
\hline & $\begin{array}{c}\text { F.CHD } \\
\text { (mm, } \\
\text { Figure } \\
\text { 1. [6]) }\end{array}$ & $\begin{array}{c}\text { F.CHD } \\
\text { (calculated, } \\
\text { 1st stage) }\end{array}$ & $\begin{array}{c}\text { F.CHD } \\
\text { (adjusted) } \\
(100,000)\end{array}$ & $\begin{array}{c}\text { M.CHD } \\
(100,000)\end{array}$ & $\begin{array}{c}\text { Pigs } \\
(1,000)\end{array}$ & $\begin{array}{l}\text { Pig } \\
\text { autopsies } \\
\text { (N) }\end{array}$ & $\begin{array}{c}\text { Pigs } \\
\text { autopsied } \\
(1 / 100,000)\end{array}$ & $\begin{array}{c}\text { Pig. } \\
\text { MAP.a-\% }\end{array}$ & $\begin{array}{c}\text { Pig.CVD. } \\
\text { tot.a-\% }\end{array}$ & $\begin{array}{c}\text { Pig. } \\
\text { MyCD.a-\% }\end{array}$ & $\begin{array}{c}\text { Pig. } \\
\text { HeD.a-\% }\end{array}$ & $\begin{array}{c}\text { Pig. } \\
\text { SMuD.a-\% }\end{array}$ \\
\hline 1951 & 85.5 & 123.9 & 122 & 410 & 442 & 446 & 101 & & & 3.14 & & \\
\hline 1952 & 78 & 114.4 & 113 & 388 & 414 & 428 & 103 & & & 7.24 & & \\
\hline
\end{tabular}




\begin{tabular}{|c|c|c|c|c|c|c|c|c|c|c|c|c|}
\hline 1953 & 70 & 105.1 & 104 & 363 & 434 & 405 & 93 & & 15.8 & 7.16 & 13.33 & \\
\hline 1954 & 62.5 & 97.1 & 96 & 371 & 546 & 513 & 94 & 1.8 & 13.3 & 6.04 & 15.20 & 0.58 \\
\hline 1955 & 69.5 & 104.6 & 103 & 385 & 467 & 248 & 53 & 2.8 & 22.6 & 14.52 & 16.13 & 2.02 \\
\hline 1956 & 59 & 93.5 & 92 & 368 & 436 & 287 & 66 & 4.2 & 18.8 & 5.92 & 10.80 & 1.74 \\
\hline 1957 & 53 & 87.8 & 86 & 358 & 534 & 449 & 84 & 7.8 & 18.5 & 5.12 & 13.59 & 0.67 \\
\hline 1958 & 54.5 & 89.2 & 88 & 361 & 534 & 394 & 74 & 9.1 & 18.5 & 4.31 & 25.89 & 1.27 \\
\hline 1959 & 57 & 91.6 & 90 & 383 & 467 & 510 & 109 & 6.9 & 12.9 & 1.76 & 19.22 & 0.98 \\
\hline 1960 & 58.5 & 93.0 & 92 & 392 & 483 & 444 & 92 & 5.9 & 13.1 & 4.50 & 12.16 & 3.15 \\
\hline 1961 & 64.5 & 99.2 & 98 & 421 & 534 & 560 & 105 & 5.9 & 12.3 & 3.93 & 15.00 & 2.68 \\
\hline 1962 & 73 & 108.5 & 107 & 468 & 626 & 589 & 94 & 8.0 & 18.8 & 5.26 & 8.49 & 3.40 \\
\hline 1963 & 69.5 & 104.6 & 103 & 472 & 577 & 406 & 70 & 10.8 & 20.2 & 5.42 & 9.61 & 1.48 \\
\hline 1964 & 65.5 & 100.2 & 99 & 501 & 600 & 634 & 106 & 11.5 & 17.0 & 2.05 & 4.10 & 0.95 \\
\hline 1965 & 67.5 & 102.4 & 101 & 501 & 595 & 782 & 131 & 9.3 & 12.7 & 0.64 & 3.84 & 0.26 \\
\hline 1966 & 63.5 & 98.1 & 97 & 505 & 651 & 709 & 109 & 7.1 & 11.3 & 1.27 & 4.09 & 1.83 \\
\hline 1967 & 71.5 & 106.8 & 105 & 515 & 771 & 807 & 105 & 8.3 & 14.4 & 1.36 & 2.60 & 1.49 \\
\hline 1968 & 65 & 99.7 & 98 & 512 & 720 & 664 & 92 & 7.5 & 14.6 & 1.20 & 4.82 & 1.20 \\
\hline 1969 & 57.5 & 92.1 & 91 & 495 & 797 & 740 & 93 & 6.4 & 13.0 & 1.08 & 4.32 & 0.95 \\
\hline 1970 & 55.5 & 90.1 & 88 & 477 & 1047 & 949 & 91 & 6.5 & 13.9 & 1.05 & 2.53 & 0.42 \\
\hline 1971 & 57 & 91.6 & 90 & 506 & 1183 & 947 & 80 & 4.5 & 5.8 & 0.00 & 2.11 & 0.21 \\
\hline 1972 & 52.5 & 87.3 & 85 & 470 & 1093 & 581 & 53 & 5.0 & 5.5 & 0.00 & 1.89 & 0.69 \\
\hline 1973 & 51 & 85.9 & 84 & 465 & 1190 & 560 & 47 & 5.9 & 9.8 & 0.00 & 2.32 & 0.18 \\
\hline 1974 & 47.5 & 82.8 & 82 & 462 & 1098 & 629 & 57 & 4.0 & 5.7 & 0.00 & 1.43 & 0.16 \\
\hline 1975 & 46.5 & 81.9 & 81 & 453 & 1078 & 1021 & 95 & 4.0 & 6.9 & 0.49 & 0.69 & 0.59 \\
\hline 1976 & & & 80 & 469 & 1097 & 941 & 86 & 1.8 & 4.9 & 0.11 & 0.43 & 0.32 \\
\hline 1977 & & & 73 & 469 & 1191 & 489 & 41 & 5.7 & 6.5 & 0.00 & 1.02 & 0.61 \\
\hline 1978 & & & 73 & 442 & 1287 & 560 & 44 & 2.3 & 2.9 & 0.00 & 1.79 & 1.25 \\
\hline 1979 & & & 74 & 416 & 1329 & 486 & 37 & 2.1 & 2.7 & 0.00 & 0.62 & 1.23 \\
\hline 1980 & & & 63 & 390 & 1450 & 487 & 34 & 7.6 & 9.0 & 0.00 & 0.82 & 0.41 \\
\hline 1981 & & & 65 & 392 & 1501 & 539 & 36 & 5.6 & 7.1 & 0.00 & 0.19 & 0.93 \\
\hline 1982 & & & 59 & 376 & 1500 & 438 & 29 & 5.7 & 5.9 & 0.00 & 0.46 & 0.23 \\
\hline 1983 & & & 56 & 349 & 1466 & 502 & 34 & 2.0 & 6.6 & 0.00 & 0.40 & 0.00 \\
\hline 1984 & & & 56 & 347 & 1382 & 530 & 38 & 4.3 & 9.8 & 0.00 & 0.19 & 0.38 \\
\hline 1985 & & & 56 & 347 & 1295 & 636 & 49 & 1.9 & 4.1 & 0.00 & 0.16 & 0.94 \\
\hline 1986 & & & 54 & 322 & 1323 & 583 & 44 & 1.9 & 7.0 & 0.00 & 0.00 & 0.86 \\
\hline 1987 & & & 58 & 291 & 1342 & 455 & 34 & 2.2 & 6.4 & 0.00 & 0.22 & 0.00 \\
\hline 1988 & & & 53 & 280 & 1305 & 626 & 48 & 2.7 & 4.5 & 0.00 & 0.16 & 0.48 \\
\hline 1989 & & & 45 & 275 & 1291 & 750 & 58 & 1.1 & 5.7 & 0.00 & 0.27 & 0.27 \\
\hline 1990 & & & 43 & 254 & 1394 & 986 & 71 & 1.8 & 7.9 & 0.00 & 0.10 & 0.10 \\
\hline 1991 & & & 37 & 236 & 1344 & 1354 & 101 & 0.5 & 3.3 & 0.15 & 0.52 & 0.00 \\
\hline 1992 & & & 35 & 223 & 1298 & & & & & & & \\
\hline 1993 & & & 33 & 202 & 1273 & & & & & & & \\
\hline 1994 & & & 31 & 191 & 1298 & & & & & & & \\
\hline 1995 & & & 29 & 181 & 1400 & & & & & & & \\
\hline 1996 & & & 27 & 171 & 1395 & & & & & & & \\
\hline 1997 & & & 23 & 157 & 1467 & & & & & & & \\
\hline 1998 & & & 28 & 150 & 1401 & & & & & & & \\
\hline 1999 & & & 23 & 146 & 1351 & & & & & & & \\
\hline 2000 & & & 25 & 149 & 1296 & & & & & & & \\
\hline
\end{tabular}




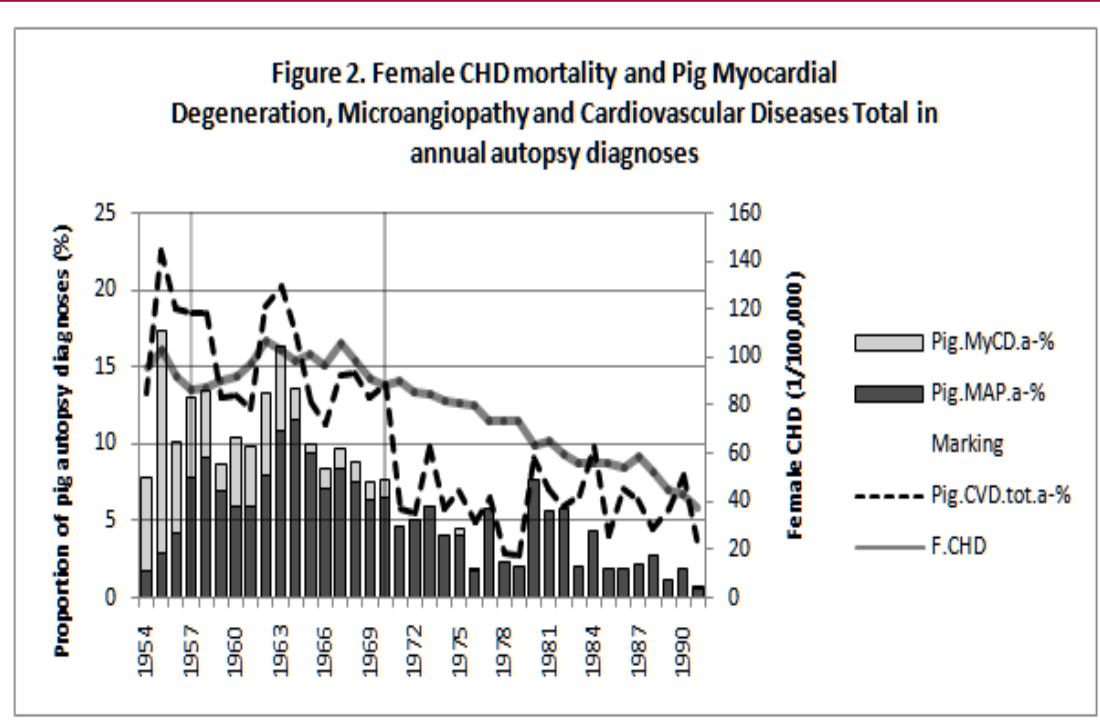

Figure 2: Shows development in female CHD and in autopsy proportions of pig CVD.tot, MAP and MyCD. MAP was increasing until 1964. This figure shows the changes in pig MAP.a- $\%$ and its periodical deviation from CVD.tot.a-\%

\section{Results}

In visual analyses remarkable is the great proportion of MyCD in CVD in 1954-55 and the steep MyCD decline after 1963, discontinuing since 1970 (Figure 1). Between 1954 and 1968 A.1/100,000 and CVD.tot were inversely associated (Figure 1). Autopsies in Kuopio and Seinäjoki are associated slowly with the autopsy density increase since 1982 (Figure 2). During 195486 Autopsy density, [MAP.a-\%] (Figure 3), [CVD.tot.a-\%] and combined regressions with [MAP.a-\%;A.1/100,000] and [CVD.a$\% ; A .1 / 100,000]$ explained better F.CHD than M.CHD (Figures 4 \& 5). All the female associations were significant (weakest by MAP.a-\%: $p=0.001$, not below 0.001). Autopsy density associated stronger than other single parameters with F.CHD and M.CHD (Table 2).

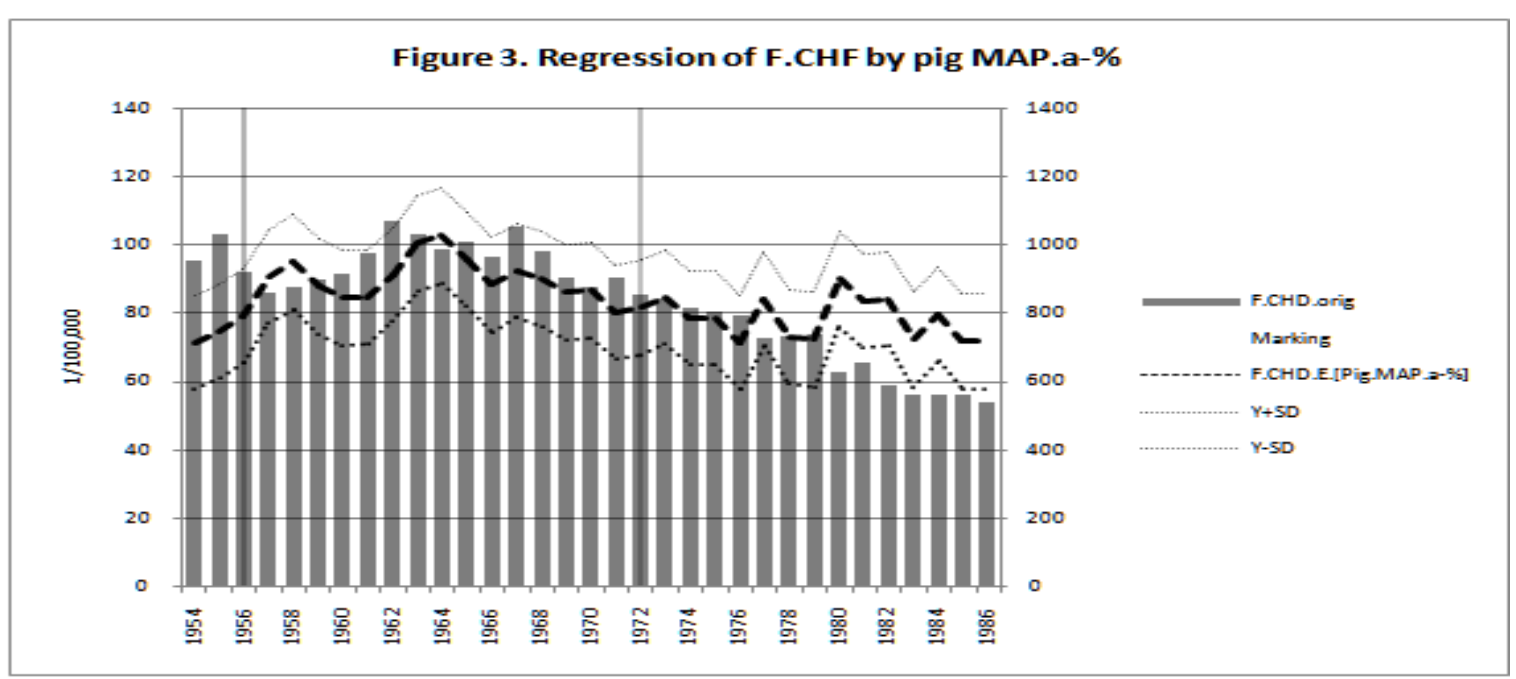

Figure 3: Represents Female CHD and its regression by [MAP.a-\%]. They have a top between 1956 and 1972. In $1954-55$ differences can be based on changes in differential diagnoses or selection of primary cause of mortality.

Table 2: Female and male CHD and their associations with pig autopsy parameters. Pig diagnoses are given as autopsy percents (without postsuffix a-\%)

\begin{tabular}{|c|c|c|c|c|c|}
\hline & A.1/100,000 & MAP & CVD.tot & [MAP.a-\%; A.1/100,000] & [CVD.a-\%; A.1/100,000] \\
\hline F.CHD & $60.1^{* * *}$ & $28.4^{* *}$ & $48.7^{* * *}$ & $63.3^{* * *}$ & $74.4^{* * *}$ \\
\hline M.CHD & $25.4^{* *}$ & $19.3^{*}$ & $0.1 \mathrm{~ns}$ & $30.4^{* *}$ & $30.6^{* *}$ \\
\hline
\end{tabular}

Significance: * resp. p $<0.05,{ }^{* *}$, resp. p $<0.01,{ }^{* * *}$ resp. $p<0.001$ 


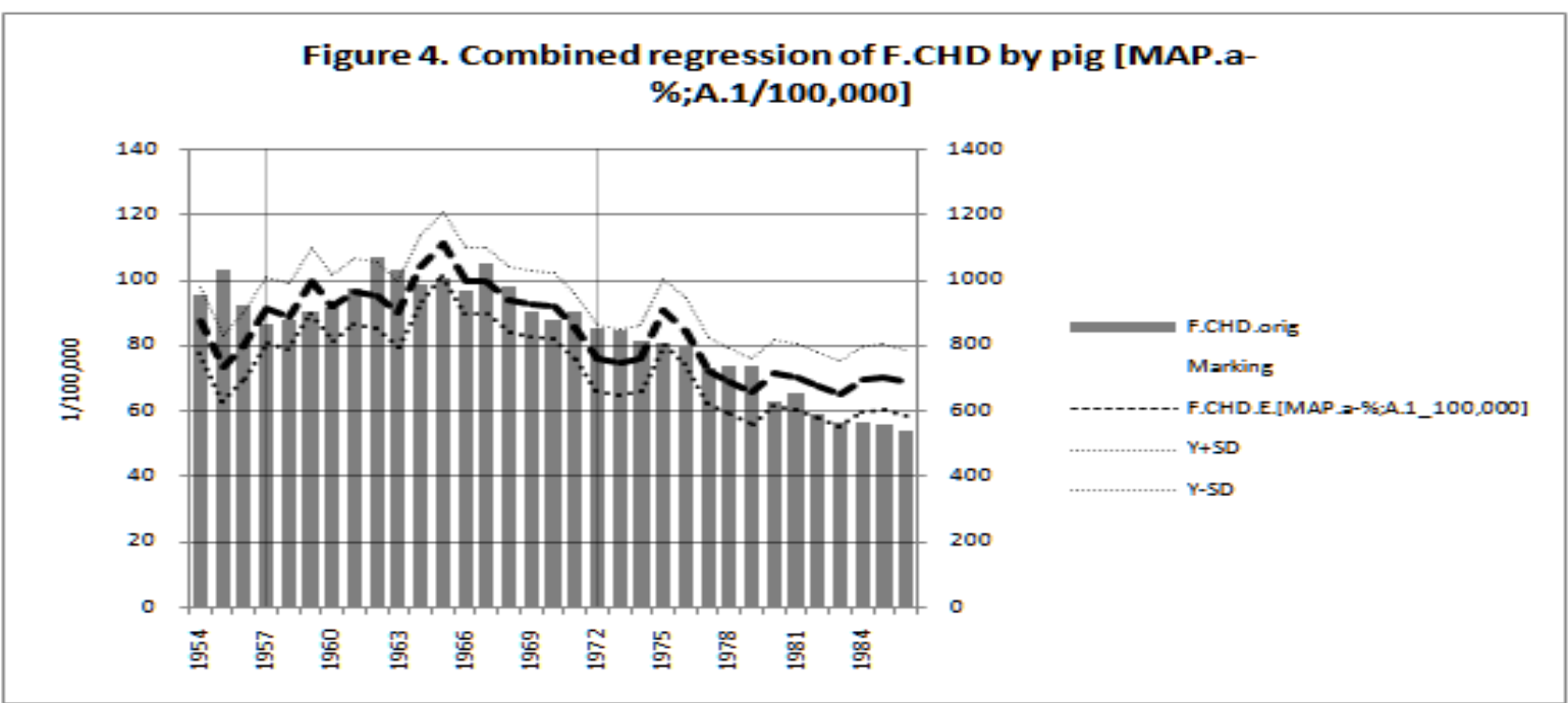

Figure 4: Shows Female CHD and its combined regression by [MAP.a-\%;A.1/100,000]. They have a top between 1957 and 1972.

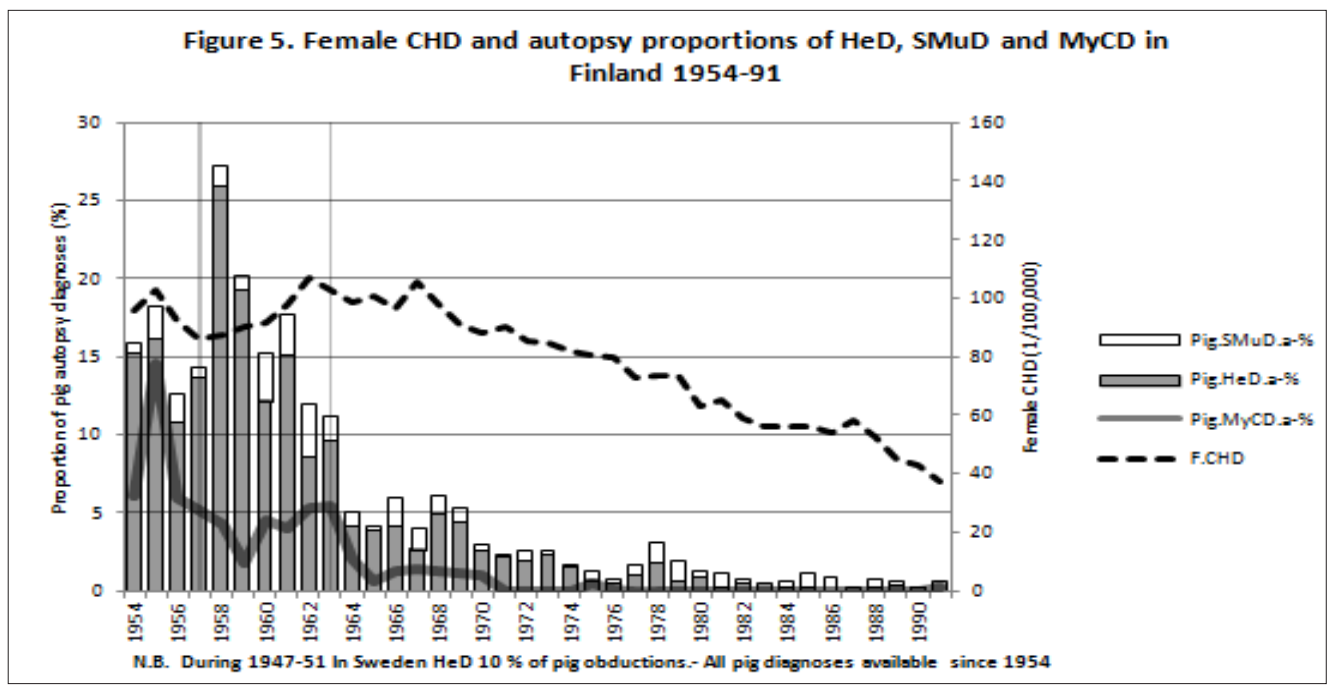

Figure 5

\section{Discussion}

This study shows that F.CHD associates better than M.CHD with cardiac mortality of pigs as expected, because of lower female tobacco consumption (discussed in [12]). The association was strongest during 1957-76 [Fig. 3]. The proportion of annual autopsies of pig population was small, about 1/1000 (or less, because the number of pigs, life span 6 months, was measured once a year $[15,16,17,18])$. The variation in autopsy density was high. Anyhow autopsy density associated significantly with pig MAP variation especially in 1957-72 [Fig. 1, Tabl. 2] - during the absolute F.CHD epidemic. Rapid increase in 1957. F.CHD during 1957-62 seems to need additional factors to fertilization or soil data [12,21]. Because of tobacco contamination male population is not discussed more.

One additional factor was clover reduction in fodder from 25 [23] to 8-9 \% [24] between 1950 and 1967. This could have indicated Mg and Si deficiency [22] in soil and fodder and in milk composition in human and pig nutrition.

\section{Selenium}

Se experiments with pig begun slowly by veterinary surgeons after 1960 and reduced HeD mortality from 10 to $2 \%$ [25]. Selenium and vitamin E containing fodder salt mixture came to agricultural stores (without advertisements) before Oct 1, 1963 [26]. The permission of such a free sale was based on field trials [27]. Single permissions were given for Se supplementations for fodder before 1968 [28]. Resolution of Ministry of Agriculture freed all commercial fodder and fodder salt mixtures from separate permissions and defined the accepted contents of Se for fodder and fodder salt mixtures since Jan 1970 [29].

HeD.a-\% was all the period 1953-61 in Finland above $10 \%$ [Table 1.], the mean HeD.a-\%, in Sweden in 1947-51) [10], and declined below it steeply since 1963 [Fig.6]. HeD.a-\%, which can be seen as a peroxide-antioxidant indicator [2], is here associated 
with MyCD.a-\% [Fig.6] and could have had cumulative effects on slowly growing human atheromas. The obvious changes in food $\mathrm{Si}$ content [22] could have been similar by pigs and humans, but Se availability was remarkably lower by humans before the beginning of Se fertilization in the 1980's [12]. In human medicine Se is not included in general cardiac medicines [30]. HeD.a-\% is a better measure of mortality, than morbidity.

\section{Quality changes in grain other than associated with mineral element contents}

The association of wet autumns with $\mathrm{HeD}$ and SMuD was known before 1962 [25]. Fresh grain risk on pig HeD was known before 1953 [10], why it had been advised not to use the grain during a few months after threshing, but this advise was not often possible to follow [25]. In the 1950's a remarkable part of pig foodstuffs was often old human waste food with poor quality.

a) Geography: During the II World War Finland lost $10 \%$ of its cropland, which had to be replaced by clearing land to soils less ideal for agricultural purposes, mainly towards northeast from the line Kokkola - Kotka. During 1959-87 cleared land amounted ca 200,000 ha and its NE/SW ratio was 3:1 [31].

1957-65 number of Combine-threshers increased 5-fold $(3,400-16,500)[32,33] .1965$ more than $50 \%$ of the seed grain was threshed by them [34], obviously the same concerning fodder and bread grain. Combine-threshers needed ca 10 days longer growing period [32] in situation, when there was threat of nonripening, frost, and preterm germination [34]. The moisture of grain to be removed increased about 2-3-fold to the old methods (with preceding drying in stalk), (from 2-5\% to 8-12\% [33] and the grain was not as homogenously ripened as by old methods. The drier capacity could not follow the new needs: In Ib1961 was written: "It should be possible to dry the grain within 24 hours after threshing" [35]. Even in 1965: "The insufficient drier capacity is the main cause of grain quality problems" [36].

Grain quality determination by microscope (sprouting) did not predict baking quality. Invisible premature germination in cob, mechanical and microbiological changes had been(in 1964) suggested to be more important factor than germinability in (acceptable) baking quality [37]. A new method for grain quality valuation, falling number (amylase activity indicator) came obligatory for all commercial grain since autumn 1966 [39]. Anyhow in 1966 [38]. Germination is associated additionally with activation of several other enzymes, as lipases [40]. Possibly the lipase activity is the cause of "unstable fats", the ability of grain to produce peroxides[2,3].

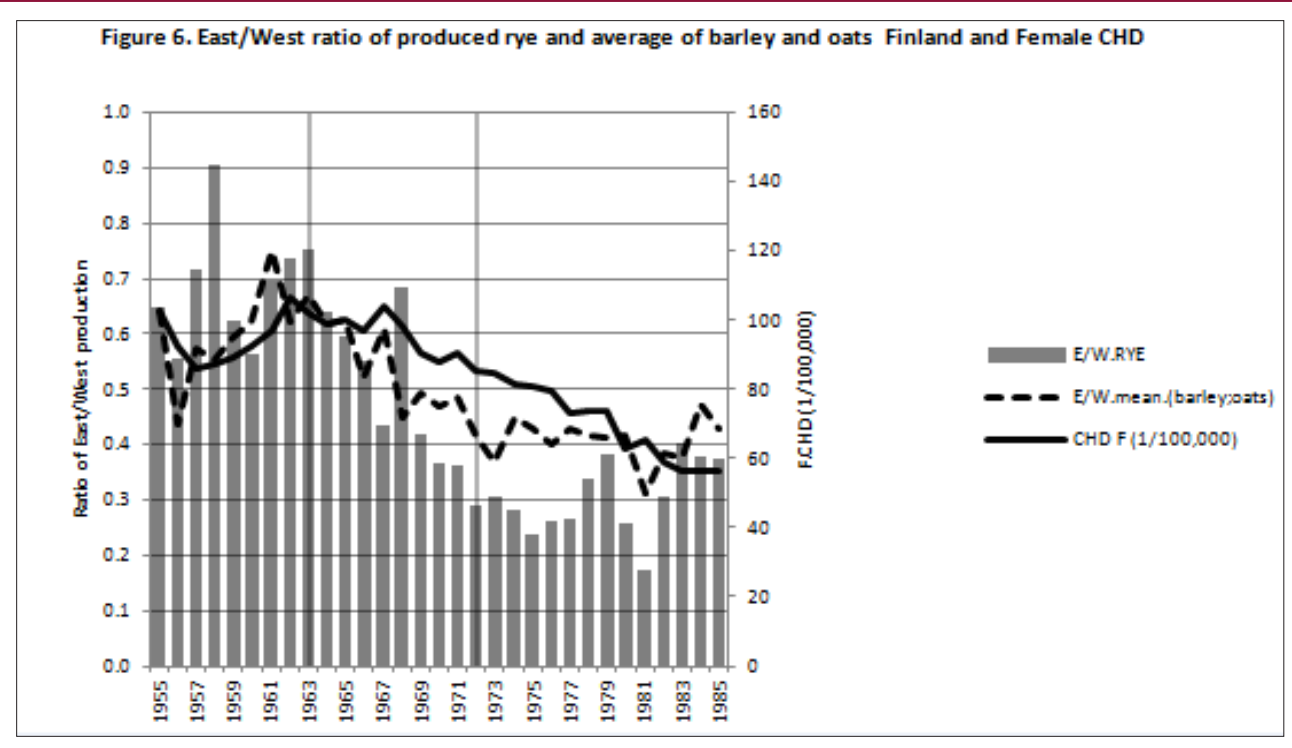

Figure 6

Thafvelin (1960) [2] discovered that heating the grain before grinding/milling could destroy the peroxides of (obviously preterm germinated) grain and protect pigs against liver, muscle and heart damages (HeD, SMuD and MAP) and death. First in 1966 was reported in Finnish journal on a Swedish experiment, which showed that grain rapidly heated to $100-105{ }^{\circ} \mathrm{C}$ had higher nutritional value for livestock than slowly heated [40]. Anyhow without data concerning fodder peroxides (same as in general after 1960).

During the 1960's wet grain problem has been counteracted by increasing number of combine-threshers (selection of better weather became possible) [32,33] and drier capacity and quality and post-harvesting technology in general, especially for avoiding germination in the loads on lorries waiting hours their turn to the drier. High quality driers could save better the fertility, too. Anyhow rancidification can slowly occur after grinding.

Se and vitamin E obviously protect us from the main harms of excessive peroxides, but food chain monitoring from field to mouth may need monitoring. Maybe the role of peroxides is higher in the non-CHD mortality (e.g. muscle and liver diseases) and gastronomy. Possibly gastronomy can have valuable indicators of food health (France!).

Problems with grain quality shifted grain production towards southwest (from the first half of the 1960's) [41]. This was 
associated with changes in female CHD (Figure 6). (East Finland is the usual name of the part of Finland towards NE from the line Kokkola-Kotka).

b) Other: During 1958-64 in Finland was benefited diluted NH4HSO4 salt mixture ("AIV salt") for conserving silage [42]. This could have been reduced $\mathrm{Mg}$ availability, by forming insoluble MgNH4PO3 in the gastro-intestinal tract of cows [43]. As food additive in some cheese breeding was benefited $\mathrm{KClO}_{3}$ to avoid Clostridium contamination from the 1950's until 1972 [43,44]. Haaranen observed increased MAP frequency associated with whey feeding in surroundings of cheese factories, $[20,43]$, which could be explained by peroxide $\left(\mathrm{KClO}_{3}\right)$ effect.

Remarkable psycho-social change was the reduction of 300,000 horses during 1950-69 [45,46]. The loss of men's best friends obviously affected more Finnish males than females or pigs and could partially explain lower M.CHD on rural than urban areas before 1969 [13]. Pig MAP ("enzootisher Herztod") , first represented in autopsy analyses since 1954, seemed (indirectly) to have been an increasing, not-well defined disease of "wellbeing" pigs in 1954-57 [43], but had been referred earlier with different labels [20]. Possibly MAP definition was not clear before 1961 [3]. Some of "CVD.tot" diagnoses are represented so unevenly that possibly they were included in group "Others" (or in MAP?). Pericarditis, a symptom of MAP, disappeared totally, myocarditis and endocarditis nearly totally during 1971-79 from autopsy summary analyses. Fig. 2 suggests that they were included in "Others" during that period.

\section{Conclusion}

Pig cardiac mortality associated significantly with female CHD, less significantly with male CHD. These associations seem possible to be explained by variation inside the foodstuffs and different smoking habits. Food peroxides are discussed. Different opinions and the great database of veterinary surgeons suggest that co-operation by faculties of human and veterinary medicine is desirable.

\section{References}

1. Koivistoinen P, Ahlström A, Nissinen H, Pekkarinen M, Roine P (1970) Mineral Element Compositions of Finnish Diets Part I: Fe, Cu, Mn, Zn, Mg, $\mathrm{Na}, \mathrm{K}, \mathrm{Ca}$ and P. Suomen Kemistilehti B43 pp. 426-430.

2. Thafvelin B (1960) Role of cereal fat in production of nutritional disease in pigs. NATURE 188: 1169-1172.

3. Grant CA (1961) Morphological and aetiological Studies of Dietetic Microangiopathy in Pigs ("Mulberry Heart"). Acta Veterinaria Scandinavica 2(3): 107.

4. Nuoranne P (1974) Magnesium deficiency in pigs ["Sikojen magnesiumin puutteesta "- in Finnish with a short English summary]. Suomen Eläinlääkärilehti. Finnish Veterinary Journal 80: 258-268.

5. Korpela H (1991) Hypothesis: increased calcium and decreased magnesium in heart muscle and liver of pigs dying suddenly of microangiopathy (mulberry heart disease): an animal model for the study of oxidative damage. J Am Coll Nutr 10(2): 127-131.

6. http://huslab.fi/ohjekirja/4601.html
7. Prikoszovits A, Schuh M (1995) The mineral content of calcium, phosphorus and magnesium in the serum and bones and the serum activity of alkaline phosphatase in slaughtered fattening pigs. Dtsch Tierarztl Wochenschr 102(1): 53-55.

8. Shechter Michael (1999) Oral magnesium supplementation inhibits platelet-dependent thrombosis in patients with coronary artery disease. American Journal of Cardiology 84(2): 152-156.

9. Poukka R (1965) Changes in the lipids of heart muscle, skeletal muscle and liver of calves suffering from muscular dystrophy. Dissertation May 22, 1965. Helsinki.

10. Obel AL (1953) Studies on the morphology and etiology of so called toxic liver dystrophy (hepatosis diaetetica) in swine. Acta Path Microbiol Scandinavica 94: 1-119.

11. Esterbauer H, Wäg G, Puhl H (1993) Lipid peroxidation and its role in atherosclerosis. British Medical Bulletin 49(3): 566-576.

12. Töysä T, Hänninen H (2017) Mg/Ca ratio in fertilization and agricultural soils, Mg percent of liming agents and human mortality in Finland during 1961-90. J Afr Ass Physiol Sci 5 (1): 29-40.

13. Valkonen T, Martikainen P (1990) Development of mortality from ischaemic heart disease in subgroups of the population in Finland. Sosiaalilääketieteellinen Aikakauslehti, Journal of Social Medicine 27: 273-288.

14. Age adjusted coronary mortality (I20-I25) of women, 35-64 yrs, in Finland in 1969-2000. Source: (C) Statistics Finland, Causes of Death.

15.1953-59: Statistical Yearbook of Finland 1960, Table 82.

16.1960-68: Statistical Yearbook of Finland 1969, Table 78.

17.1969-78: Statistical Yearbook of Finland 1978, Table 71.

18. 1979-91: Statistical Yearbook of Finland 1998, Table 93.

19. Autopsy statistics (1957) Annual reports of National Veterinary Institute (Valtion eläinlääketieteellisen laitoksen vuosikertomukset) 1957-91. Department of Pathology, National Veterinary Institute, Helsinki. Years 1950-91.

20. Haaranen S. 1957. Some observations about s.c. fatale syncope in swine. [Finnish Veterinary Journal] Suomen Eläinlääkärilehti 1957:543-565. ("enzootischer Herztod" on page 555).

21. Toysa T (2016) Compliance of Finnish Male CHD and Total Mortality with Soil Fertilization in 1957-1990. J J Agriculture 2(1): 013.

22. Toysa T. Regional Groundwater Hardness and Silicon, Cropland Fertility and CHD in Finland. Biomed J Sci \& Tech Res 2(1)- 2018.

23. Paatela J.1953. Acta Agr Fenn 79.1:1-81 (in Ritola U. About biological nitrogen fixation. [in Finnish]. Luonnonmukaisen viljelyn perusteet. Vaihtoehtoisen viljelyn opintopiiri. Helsinki 1980. on p. 96).

24. Jäntti A. 1968. About benefits of abundant N fertilization on pasturesilage grass. [In Finnish]. Karjatalous 1968;3:82-(85). (non-precise reference of Mukula J: clover proportion 8-9\% of the hay crop in196667.)

25. Holcombe R, Holcombe RB. The use of Se compounds in the prevention and medication of Hepatosis diaetetica of pigs [in Finnish]. Suomen eläinlääkärilehti: 219-225, 1962.

26. Kiiskinen T. Head of Veterinary Department of Vaasan Höyrymylly Oy Oct 1, 1963 - 1971. Personal communication (letter) March 2, 2012.

27. Hyppölä K. Combined Selenium and vitamin E therapy has given promising results in muscle dystrophy. [in Finnish]. Karjatalous 1962;(1):25.

28. Haarasilta A. Personal communication. Fodder and fodder salt mixtures were supplemented with Mg and Se before Jan 1, 1968, when he begun his work as nutritionist as an nutritionist in fodder factory of OTK. 
29. Resolution N:o 1670/33 -69 Dec 8, 1969 of Veterinary Department of Ministry of Agriculture.

30. Munguti CM, Al Rifai M, Shaheen W. A Rare Cause of Cardiomyopathy: A Case of Selenium Deficiency Causing Severe Cardiomyopathy that Improved on Supplementation. Cureus. 2017 Aug 29;9(8):e1627. doi: 10.7759/cureus.1627.

31. Maatilahallituksen tilastot: Maatalouden peruslaskenta 1969, Maatilarekisterit 1972-82. Statistics of the National Board of Agriculture: Agriculture Census 1969, Farm Register 1972-82.

32. Combine-threshers: 1954-58: Kukkonen J. Combine-threshing in Finnish circumstances [in Finnish]. Käytännön Maamies 1958:7:288-9.

33. Combine-threshers: 1961-2005 http://www.fao.org/faostat/en/\#data $>$ Investments > Machinery Archive > Finland, 1961-2005. In Use (Accessed Apr 24, 2017).

34. Schildt R. Spring seed quality in the light of a sample survey [in Finnish]. Pellervo 3/1967. p. 136-138.

35. Sipilä M. Combine-threshing and grain drying. [in Finnish]. TEHO 1961:"7/8". 369-376.

36. Näri O, Kuukankorpi P, Pohjanheimo O. "Quality is trump" [in Finnish]. Pellervo 8/1965. p. 378

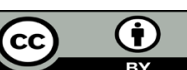

This work is licensed under Creative Commons Attribution 4.0 License

Submission Link: http://biomedres.us/submit-manuscript.php
37. Kuukankorpi P. 1964. Preterm germination from the viewpoint of miller [in Finnish]. Pellervo 1/1964:10-11.

38. Karjalainen J. (1966). Why bread grain to fodder? [in Finnish]. Karjatalous.1966:9:266-268.

39. PalmianoEP, Juliano BO.1973. Changes in the Activity of Some Hydrolases, Peroxidase, and Catalase in the Rice Seed during Germination. Plant Physiol 1973;52:274-7.

40. Peers FG. 1953. Nature, Lond, 171:981, in Martin HF, Peers FG. 1953. Oat Lipase. Biochem 55:523-9.

41. Crops, Rural Centres 1955-85. Maataloustilastolliset kuukausikatsaukset / Maataloushallitus (Statistical monthly reports on Agriculture/National Board of Agriculture).

42. Silage salt. (in Finnish silage salt). [in Finnish]. Maatalouskalenteri 1957, $-59,-59,-60,-61,-62,-63,-64,-65$, but not after 1965. [In Finnish]

43. Personal communication, Haaranen Töysä

44. Information provided by the Valio Laboratory: Decision of the FAO/ WHO "Milk Committee: "Special salt" against false fermentation is after autumn 1972 prohibited. [in Finnish] Karjatalous 11/1972, p. 472. Valio.

45. Statistical Yearbook of Finland 1962, Table 83.

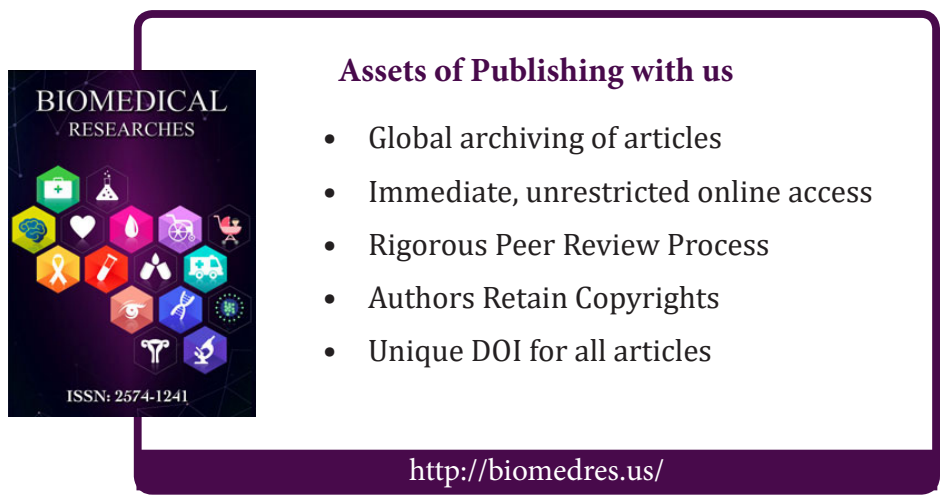

